\title{
Review
}

\section{The practice of political theory: Rorty and continental thought}

\author{
Clayton Chin \\ Columbia University Press, New York, 2018, xi + 293 pp., \\ ISBN: 978-0-231-17398-8
}

Contemporary Political Theory (2020) 19, S221-S224. https://doi.org/10.1057/s41296019-00332-0; Published online 2 July 2019

Why Richard Rorty now? A long time has passed since it was commonplace to pay him the tribute, with varying degrees of affection and irritability, of ritual denunciation and/or to preface papers with a seemingly obligatory prophylactic warning to the effect that, whatever far-fetched assertion was on its way, it did not, of course, go as far as Rorty.

In this timely and significant book, Clayton Chin contributes to an important new wave of writing about Rorty and pragmatism that seeks to offer a bracingly positive answer to this question. He painstakingly puts Rorty's work in conversation with a range of contemporary theoretical positions, which he gathers under the rubric of continental political thought. Wisely narrowing the scope of the latter, Chin in particular seeks to tease out the relationship between Rortyan pragmatism and the kind of approach captured a little while ago by Stephen White's concept of 'weak ontology'. While these perspectives share criticisms of ideal liberal theory, rejecting what they take to be its excessively abstract normative vision, they provide two contending pathways for a post-foundational conception of political theory. Weak ontologists think that some particular view of political reality, 'both fundamental and contestable, both unavoidable and ungrounded' (p. 16), is needed in order to ground political claims. For the Rortyan pragmatist, there is only 'cultural politics', the process of trying to provide more fruitful, humane and useful descriptions: the ontologists' effort to get things right is just likely to be a relatively fruitless endeavour. In elaborating this contrast, Chin reads Rorty as making a distinctive theoretical intervention 'at the meta-level, concerned with the conditions of possibility of inquiry. The main task of the theoretician is to negotiate between our various vocabularies' (p. 60). This surprisingly Kantian-sounding project 'can structure interframework dialogue, as a shared linguistic practice, in a way that avoids presuming the standards of any particular perspective, while remaining reflective and critical' (p. 60). Chin develops this argument in the three parts of his book.

(C) 2019 Springer Nature Limited. 1470-8914 Contemporary Political Theory Vol. 19, S3, S221-S224 
Part 1 outlines the contours of Rorty's work, from the earlier Peirce- and Wittgenstein-inspired reflections on metaphilosophy, via the critique of epistemology in Philosophy and the Mirror of Nature and its invocation of hermeneutics as an alternative philosophical method, to the later Deweyan-inspired (however interpretatively dubious) project of locating authority in human purpose and social practice. This last project, which Chin only sees as reaching fruition in Rorty's later work under the rubric of 'cultural politics', notoriously seeks to replace objectivity with solidarity, which Chin glosses as the obligation 'to seek as much intersubjective agreement as possible ... to subject our claims reflexively to as many linguistic challenges as possible' (p. 59). In the absence of neutral theoretical criteria, cultural-political argument is comparative, a matter of seeing what we make of alternative ways of doing things.

Part 2 weaves its way through a dense and nuanced debate between Rorty and ontologically informed continental political thought, which is distilled in the figure of William Connolly. Rorty resists the suggestion that his philosophy offers a better account of the way things really are, whereas the ontologist thinks that a claim about this, however fallible and contestable, cannot be ducked. For Connolly, the world is 'inherently pluralistic/complex/becoming/fragile/etc.', and resistant to human purposes (p. 117). From this perspective, Rorty possesses a hidden 'modernist' ontology of human mastery over the world, assuming that it is susceptible to our purposes. Chin sees Connolly as caught on a dilemma: he must either prioritise his ontological commitments or prioritise their contestability. Interestingly, Chin's response to the criticism that Rorty has a hidden ontology of mastery has a concessive element-this is a claim for mastery 'but it is only a mastery of our own social and political lives ... [which] is ideally suited to pluralistic democratic societies where competing normative standards meet in the public' (p. 144).

In Part 3, Chin outlines the normative approach that follows from this debate over ontological standing. Here he broadens the focus, drawing on Rorty's engagement with critical social theory, and particularly with followers of Habermas, who also try to thread an anti-sceptical, fallibilistic path, and with proponents of agonistic democracy. Contemporary political theory confronts pluralism along at least two dimensions, he argues. First, there is the methodological question for political theorists of how to proceed within a discipline characterised by theoretical diversity and differing ontological, epistemological and sociological assumptions that stand behind their critical diagnoses and normative prescriptions. In keeping with his view of Rorty as contributing to metatheory, Chin explores 'the methodological question of how diverse political theories should relate to one another, especially when working across traditional barriers, and still go about making critical and normative claims' (p. 203). Second, there is the political question: how can democracy respond to the multifaceted theoretical pluralism of modern societies? Here Chin sees the Rortyan agenda as 
enabling 'egalitarian engagement across linguistic-normative difference' (p. 205) and as taken forward by the kind of critical dialogue and interaction of perspectives that we find in authors such as James Tully, 'a non-transcendental yet transcending critique of the horizons of our practices and forms of thought by means of reciprocal comparison and contrast with other possible ways of being in the world' (Tully 2008: 35, quoted at p. 232).

This is a very thoughtful, sensitive and probing study. Its impressive and ambitious breadth of theoretical engagement can't help but prompt further conversation, and followers of Connolly, New Materialism, Mouffe, Habermas, and the others with whom Chin engages, will find plenty to consider in the dialectic with their respective positions. That said, the book as a whole operates at quite a high altitude: there is very little by way of illustrative example to flesh out some of the rather abstract claims about diversity and contestation, and nothing on Rorty's more specific political opinions - on the views of the cultural left, inequality and authoritarianism in Achieving Our Country that have recently been given fresh and alarming life, for example. Nor is there anything of Rorty's impish provocativeness that readers continue to find seductive or repellent. This steadiness of focus may reflect the entirely creditable desire on Chin's part to guide thinking about Rorty out of tiresome polemical grooves and take him in new directions. Yet this also suggests some ways in which the reader is left seeking more guidance about how to conduct political theory in this Rortyan key. Let me sketch a couple of brief reflections on this.

First, ontology seems to be a dimension of the theoretical pluralism that Chin takes as his starting point. One way in which we evaluate theories, or think of them as being in conflict, is through their fundamental picture of what makes up the world. We can accept this without adding in a further worry about the priority of ontology: rather, ontology is just an aspect or dimension of a developed theoretical claim. If so, then we may be entitled to take Rorty's theory as having certain ontological features, principally a focus on language and on a variety of cognate Rortyan entities such as texts, redescriptions, and conversations. And if we accept this, then there seems to be space to discuss and evaluate this conception in comparison with other ontological conceptions. I'm not suggesting that Connolly or Mouffe, for instance, offer a more persuasive set of descriptive assumptions; only that ontology can be a legitimate dimension of debate, without requiring a priority claim. Chin may want to invoke the Rortyan 'cultural politics' move in response to this suggestion to the effect that we should focus on the 'utility' of these descriptions but it's not clear that it's a move he quite embraces himself here, as opposed to attributing it to Rorty.

Second, it is not clear how eirenic Rorty's approach is at the metatheoretical level, in this kind of account. Cultural politics asks us to see our deepest commitments as contingent cultural products, the subject of 'reciprocal comparison and contrast' (p. 232) with other equally contingent products. This is a radically

(C) 2019 Springer Nature Limited. 1470-8914 Contemporary Political Theory Vol. 19, S3, S221-S224 S223 
revisionary view-definitely not an instance of philosophy leaving everything as it is. And notoriously, as Rorty recognised, it is a view that seems to require much less by way of self-transformation for, well, people like him than it does for those of us for whom validity or divinity provides an indispensable underpinning for our values. How does this then 'structure interframework dialogue $[\ldots]$ in a way that avoids presuming the standards of any particular perspective, while remaining reflective and critical' (p. 59)?

It is testimony to the quality of this book that it provokes this kind of question, of course. Chin has provided an indispensable contribution to thinking about Rorty, pragmatism and new paths for political theory.

\section{Reference}

Tully, J. (2008). Public Philosophy in a New Key: Democracy and Civic Freedom (Vol. 1). Cambridge: Cambridge University Press.

Publisher's Note Springer Nature remains neutral with regard to jurisdictional claims in published maps and institutional affiliations.

Matthew Festenstein

University of York, York YO10 5DD, UK matthew.festenstein@york.ac.uk 